\title{
THE DEVELOPMENT OF THE USE OF EXPERT TESTIMONY
}

\author{
LLOYd L. ROSENTHAI*
}

\section{INTRODUCTION}

The determination of a matter in litigation in the present system of administering justice depends on two things: (I) a finding that certain operative facts exist or existed; (2) an application of a guiding principle or rule to such facts, whereupon a final judgment is rendered. To accomplish the first of these there has been developed a highly technical set of rules comprising the law of evidence, the purpose of which is to select the material which should be considered by the trier of fact.

Thayer defines evidence as

"a term of forensic procedure [which] imports something put forward in a court of justice. ... The law of evidence has to do with the furnishing to the court of matter of fact, for use in a judicial investigation." 1

Wigmore analyses the meaning of evidence as

"Any knowable fact or group of facts, not a legal or logical principle, considered with a view to its being offered before a legal tribunal for the purpose of producing a persuasion, positive or negative, on the part of the tribunal, as to the truth of a proposition, not of law or of logic, on which the determination of the tribunal is to be asked."2

The theory of the law is that when such material or evidence is put before the trier of fact, the findings of fact will depend upon the conviction made upon the minds of a rational group of men. In other words, the finding of the operative elements of any litigated transaction depends upor the reasoning process of persons with the ordinary degree of knowledge and experience, who make necessary inferences. We find expression of this concept of the modern trial as early as Bushell's Case, $^{3}$ decided in I67I, where it is said:

- B.A., I932, LL.B., I934, Cornell. Research Assistant for the Law Revision Commission of the State of New York. Member of the New York Bar.

This article is based on a study prepared by the writer under the direction of John W. MacDonald, Executive Secretary and Director of Research of the. Law Revision Commission of the State of New York.

1 Thayer, A Preliminary Treatise on Evidence at the Conmon Law (i 898) 264.

2 I Wigmore, a Treatise on the Angzo-American System of Evidence in Trials at Common Law (2d ed. 1923) \$r.

Vaughan 135, at 142 ( $167 \mathrm{r}$ ). This case determined the independence of the jury in rendering its verdict. Bushell was one of a jury which acquitted two Quakers despite the direction of the presiding judge, who thereupon fined each juror. Bushell refused to pay the fine and was-taken into custody 
". . . a witness swears to what he has heard or seen . . . to what hath fallen under his senses. But $a$ juryman swears to what he can infer and conclude from the testimony of such witnesses by the act and force of the understanding."

\section{Thayer says:}

"Reasoning ... the rational method of settling disputed questions is the modern substitute for certain formal and mechanical 'trials,' or tests, which flourished among our ancestors. .. . But now when we use the phrase 'trial' and 'trial by jury' we mean a rational ascertaining-of facts, and a rational ascertaining and application of rules. What was formerly 'tried' by the method of force or the mechanical following of form, is now tried by the method of reason."

But frequently there arise matters about which the ordinary degree of knowledge and experience of the trier of fact is insufficient to enable it to make all the necessary inferences. Under such circumstances the requisite knowledge and experience must be supplied to the trier of fact. It is then that the expert witness is permitted to testify.

An expert has been variously defined, both by writers and courts. Wigmore has identified the expert in connection with the subject matter of expert testimony:

"Secondly, there is that class of matters as to which it is only by means of some special and peculiar experience more than is the common possession that a person becomes competent to acquire knowledge."6

And he has also defined the expert in terms of ability to comprehend the nature of experiences falling within one's perception:

"That sort of capacity, which involves, not the organic powers, moral and mental, requisite for all testimony, nor yet the emotional power of unbiased observation and statement, but the skill to acquire accurate conceptions may be termed experiential capacity. The person possessing it is commonly termed Expert."7

\section{An expert has been termed as}

"one who is skilled in any particular art, trade, or profession, being possessed of peculiar knowledge concerning the same."8

Upon a writ of habeas corpus, it was decided that there was not sufficient ground to commit him; and he was set at liberty. Since then, juries have been free to render verdicts according to their own judgment.

'Thuyer, op. cit. supra note 1 , at 198-I99. See, too, 9 Holdsworth, A History or Enolish Law (1926), at I33-139.

-We must keep in mind that an expert may testify to facts which he has been able to observe because of his special skill; from these facts the jury may then draw the conclusions. On the other hand, he may testify to an opinion on facts for which the jury has not sufficient experience to arrive at an intelligent opinion. See Dougherty v. Milliken, 163 N. Y. 527,57 N. E. 757 (1900): “. . . in the one instance the facts are to be stated by the experts and the conclusion is to be drawn by the jury; in the other, the expert seates the facts and gives his conclusion in the form of an opinion which may be expected or rejected by the jury."

- I Wigmore, op. cit. supra note 2, 5556.

I Wigmore, op. cit supra note 2, $\$ 555$.

-Rogers, Expert Testimony (2d ed. 189x) 2. 
From the New York Court of Appeals we have it that

"an expert is one instructed by experience, and to become one requires a course of previous habit and practice, or of study, so as to be familiar with the subject."

The expert's function is to supplement the premises upon which the reasoning of the trier of fact is based with those premises obtained from his experiential qualifications, thereby endowing the trier of fact with sufficient knowledge to understand the significance of the evidence and to make the inferences. ${ }^{10}$ It is evident, therefore, that the fiat for expert testimony is necessity, born of the realization that the effective administration of justice requires aid from other branches of learning and science. As early as 1553 , when our legal institutions were still in their formative stage, it was judicially noted that:

"If matters arise in our law which concern other sciences or faculties, we commonly apply for the aid of that science or faculty which it concerns, which is an honorable and commendable thing in our law, for thereby it appears that we do not despise all other sciences but our own, but we approve of them, and encourage them as things worthy of commendation."11

It would serve no purpose to attempt an exposition of all the possible instances where expert testimony would be admissible. The only test which may be laid down with accuracy is that suggested by Wigmore: "On this subject can a jury from this person receive appreciable help?"12 Some of the many matters upon which such testimony has been admitted are: medicine, ${ }^{13} \mathrm{X}$-rays, ${ }^{14}$ electricity and electric lights, ${ }^{15}$ chemistry, ${ }^{16}$ radio tubes, ${ }^{17}$ nautical skill, ${ }^{18}$ growth of trees, ${ }^{18}$ handwriting, ${ }^{20}$ operation of street car, ${ }^{21}$ curative powers of a mineral water, ${ }^{22}$ fingerprints, ${ }^{23}$ ballistics, ${ }^{24}$

- Nelson v. Sun Mutual Insurance Co., 7x N. Y. 453, 460 (1877).

${ }^{10}$ Mayor v. Pentz, 24 Wend. 668 (N. Y. 1840); Ferguson v. Hubbell, 97 N. Y. 507,513 (1884). See Hand, Historical and Practical Considerations Regarding Expert Testimony (I901) I5 HARv. L. Rev. 40, 50-52.

${ }^{11}$ Saunders, J., in Buckley v. Rice, I Plowd. 125 (1554).

19 Wigmore, op. cit. supra note 2, \$rg23. See also In re Wells' Will, r29 Misc. 447, 453, 221 N. Y. Supp. 714 (1927).

${ }^{18}$ Hickenbottom v. D. L. \& W. R. R., 122 N. Y. 91, 25 N. E. 279 (1890); Young v. Johnson, I23 N. Y. 226, 25 N. E. 363 (1890); Stouter v. Manhattan Ry. Co., 127 N. Y. 661, 27 N. E. 805 (189r); Cross v. City of Syracuse, 200 N. Y. 393, 94 N. E. 184 (1911); In re Wells' Will, supra note 12.

14 Marion v. Construction Co., 216 N. Y. I78, I10 N. E. 444 (1915).

${ }^{15}$ Prickett v. Sulzberger \& Sons Co., 57 Okla. 567, 157 Pac. 356 (1916).

12 San Marcos Oil Mill v. Soyars, 265 S. W. 173 (Tex. Civ. App. I924).

${ }^{17}$ Bond Electric Corp. v. Gold Seal Electric Co., 244 App. Div. 206, 278 N. Y. Supp. 969 (1935).

"Walsh .v. Washington Marine Ins. Co., 32 N. Y. 427 (1865).

${ }^{10}$ Ramapo Mfg. Co. v., Mapes, 216 N. Y. 362, I10 N. E. 772 (1915).

${ }^{\circ}$ Sudlow v. Warshing, ro8 N. Y. 520, I5 N. E. 532 (1887); Pcople v. Molineux, r68 N. Y. 264, 6r N. E. 286 (Ig0r).

II Convery v. St. Ry. Co., 252 Mass. 418 , I 47 N. E. 824 (I925).

${ }^{2}$ Goodwin v. U. S., 2 F. (2d) 200 (C. C. A. 6th, 1924).

* People v. Roach, 215 N. Y. 592, rog N. E. 618 (1915).

* People v. Fisher, 340 Ill. 216, 172 N. E. 743 (1930). 
mental condition, ${ }^{25}$ alteration of coat, ${ }^{26}$ watertightness of cellar. ${ }^{27}$ And but recently expert testimony was presented to the Surrogate of New York County dealing with the probability of inflation and the effect thereof on investments, upon a petition for authority to depart from "legal investments" and to invest trust funds in common stock. ${ }^{28}$

\section{Historical Considerations}

We have said that expert testimony is admitted because it is a necessity. In the early part of our legal history when a trial was merely a submission to a mechanical process of proof, there was no need of such information. A brief survey of the four older methods of trial will show that there was no place for either an expert, or even for a witness in the modern sense. In proof by Witnesses, a party produced witnesses to swear to a belief in his story. The essence of this process was the oath itself, not its probative worth. In Compurgation or Law Wager, a defendant denied the claim on oath in a set form. If he succeeded thereafter in obtaining a certain number of persons or "compurgators" to back the denial with their oaths, he would win. The theory of trial by Battle was that victory would be obtained not only by physical force, but also by the intervention of Providence on the side of right. And trial by Ordeal was a process of proof designed to provide for heavenly intervention by some sign or miracle which would determine the question at issue between the parties. In each one of these processes, the function of the court was simply to determine which party should submit to the selected form of proof and to see that the forms were observed. ${ }^{29}$

But with the development of the institution of jury trial and its gradual displacement of the older forms of trial, adjudications were becoming the result of the reasoning process of a group of rational men upon the information which that group had before it, rather than a mere submission to an essentially mechanical test. These early juries were not the juries we know today; rather they were bodies of neighbors, already acquainted with the facts or capable of discovering them easily, who partook of the character of witnesses as much as of judges. ${ }^{30}$ There was then no settled practice of adducing information by means of sworn testimony of witnesses; "how a jury came by its knowledge was not originally a matter with which the law concerned itself." ${ }^{31}$ This practice was not general until the 16th century when the distinction between witnesses and jurors was becoming clear. By the Act of $1562-1563,{ }^{32}$ there was provided for the first time a process to compel witnesses to attend and

${ }^{*}$ People v. Youngs, 15I N. Y. 210,45 N. E. 460 (1896): In re Barney's Will, 185 App. Div. 782,174 N. Y. Supp. 242 (1919).

${ }^{2}$ Moschowitz v. Flint, 33 Misc. 480,67 N. Y. Supp. 852 (1900).

"MacKnight Flintic Stone Co. v. City of N. Y., 13 App. Div, 231, 43 N. X. Supp. 139 (1897).

In re Muller's Will, 280 N. Y. Supp. 345 (1935).

- See I Holdsworth, op. cit. supra note 4, at 299-312, for an account of the older methods of trial.

- I Hozdsworth, op. cit. supra note 4 , at $3 \mathrm{r}$, and 9 id. at $13 \mathrm{r}$.

In Holdsworth, op. cit. supra note 4, at 333-334.

s Errz. c. 9, 5 I2. 
testify in the common law courts. These early jurors were expected to make their own inquiries. Indeed, a voluntary witness was for a good time a decidedly unpopular person in the law and was quite likely to be subject to the charge of maintenance and conspiracy. This antipathy to witnesses, Holdsworth explains, was caused in large measure by the ease with which facts could be invented, so that evidence, wholly perjured, was a common danger, ${ }^{33}$ and also by the unsettled condition of the country because of which men of power would employ any means to influence a trial in their favor. ${ }^{34}$

When the jury as a rational body began to function as an integral part of the judicial system, there arose from time to time occasions when the tribunal had to have knowledge or information of a particular sort in order to decide the issues reasonably. It was the same necessity which today sanctions the employment of expert testimony. Under such circumstances there were two methods of obtaining the requisite specialized knowledge. One was to impanel a jury of persons specially qualified to pass judgment in a particular case; this was really a jury of experts. The second was for the court to summon skilled persons to inform it about those matters beyond its knowledge. If the court saw fit, it would then pass the instructions on to the jury or would be guided by them in making its own findings.

It is highly likely that the need of expert knowledge was first met by means of the special jury, inasmuch as the early juries were summoned from those acquainted with the matters in issue. During the r4th century there are many instances of juries summoned from tradesmen or craftsmen to decide questions dealing with trades or crafts. $^{35}$ Some of the matters upon which such juries were impanelled were: ( $x$ ) whether the meshes of fishing nets were smaller than required by the trade ordinance; (2) whether hides were improperly tanned; (3) whether tapestry was false; (4) whether hats and caps were improper; (5) whether wine was false; (6) whether putrid victuals had been sold; (7) whether a surgeon was guilty of malpractice. A relatively recent example of a special jury is Regina $v$. Anne Wycherley, ${ }^{38}$ wherein a jury of married women ("matrons") were impanelled to determine if the convicted prisoner was with child. This was the jury "de ventre inspiciendo," the form of the writ for which Bracton in the thirteenth century set forth in De Leg. lib. ii, fol. 69. Holdsworth says:

"Such juries are perhaps the ancestors both of the modern special jury and the modern expert witness."ar

But there are also early instances of the court summoning skilled persons to aid it on certain problems requiring a specialized experience to understand. In 1353 , in

I HoLDsworta, op. cit. supra note 4, at 334 .

" 9 HoldswORTH, op. cit. supra note 4 , at 179.

${ }^{35}$ See Hand, supra note 10 , at 41-42 for a discussion of this method of obtaining specialized knowledge.

$\because 8$ C. \& P. $262\left(183^{8}\right)$.

I7 I Holdsworts, op. cit. supra note 4, at 333. For further discussion of special juries, see ThAYER, op. cit. supra note I, at $94-97$. 
an appeal of mayhem, the court ordered the sheriff to summon surgeons from London to aid it in deciding if a wound was mayhem..$^{38}$ And in Buckley v. Rice, ${ }^{30}$ it is recorded that:

"In 7 H.6 [about $\mathrm{r}_{429}$ ] in a case that came before the judges, which was determinable in our law, and also touched upon the civil law, they were well content to hear Huls, who was a bachelor of both laws, argue and discourse upon logic, and upon the difference between compulsione praecisa et causativa, as men that were not above being instructed and made wiser by him."

Also cited in the opinion of Saunders, J., is

"a case where excommengement was pleaded against one, and the party said he ought not to be disabled thereby, because there was an appeal pending thereof, there the Judges enquired of them that were well versed in the cannon law touching the force thereof. [This was in $20 \mathrm{H} .6$, about 1442.]"

Thayer, in his Cases on Evidence, ${ }^{10}$ tells of a case in 1493 (9 H. VII) wherein Brian, C. J.,

"alleged a precedent and the case was such: a man was bound in an obligation upon a condition to pay five pounds of fine gold. ... The obligation ran puri auri... . And the masters of gramer were sent for to advise what the Latin was for 'fine,' and they could not tell." 41

In Buckley v. Rice, 22 the question was whether the use of the Latin word licet made the plaintiff's allegation bad because it thereby lacked certainty. Said Staunford, J.: "And in order to understand it (licet) truly, being a Latin word, we ought to follow the steps of our predecessors, Judges of the Law, who, when they were in doubt about the meaning of any Latin words, enquired how those who were skilled in the study thereof took them, and pursued their construction."

When experts were so summoned at this time, the information was in all probability furnished to the court rather than to the jury, whereupon the court would instruct the jury on the matters involved. Holdsworth says that "these witnesses were regarded as expert assistants to the court." 43 That skilled persons were summoned by the court seems all the more probable when we realize that these early juries were expected to decide issues from their own knowledge and that the practice of taking the testimony of witnesses was looked on askance until the 16th century.

Although there are prototypes of the modern expert witness during this time, there is no such thing as an expert witness. We can look for the expert witness only when the proof of facts by witnesses, rather than by the personal knowledge of the tribunal, becomes accepted, a change which took place during the 16 th century. ${ }^{44}$

* Thayer, Cases on Evidence (2d ed., r900), 673.

- Supra note $\mathrm{rr}$.

a This case is cited also in the opinion of Stamford, $J$., in Buckley v. Rice, supra note $\mathrm{xr}$.

Supra note $\mathrm{Ir}$.

9 Hozdsworth, op. cit. supta note 4, at 212. See, too, ThuYer, op. cit. supra note 35, at 672; 4 WIGMORE, op. cit. supra note 2, S1917; Hand, supra note ro, at 40.

I HolDsworth, op. cit. supra note 4, at $334 ; 9$ id. at 178. 
It was then that legislation was enacted to provide for compelling witnesses to appear; $;^{45}$ and it was then that proof by witness in open court, the modern method, became the ordinary accompaniment of jury trial. By the middle of the izth century the office of juror has become clearly distinct from that of witness. So during this transitional period there are cases in which skilled persons have testified before court and jury. In $x 619$ we see that physicians testified, in an ejectment action, that a child born January 5, I6II, might be the daughter of a man who died March 23, I6I0: ". . . and this being proved [misuse of the mother by the father in law after the husband's death and before the birth], and this misusage by five women of good credit, and two doctors of physic, viz. Sir William Baddy and Doctor Munford, and one Chamerlaine (who was a physician, and in nature of a midwife), upon their oath, they affirming that the child came in time convenient to be the daughter of the party who died; . . .

"The Court held here, that it might be well as the physicians had affirmed, ... and so the Court delivered to the jury, that the said Elizabeth, who was born forty weeks and more after the death of the said Edmund Andrews, might well be the daughter of the said Edmund." 46

It is not clear from the report of the case who called these physicians; but we do see that the court apparently believed the proposition and so charged the jury. In I665 in the notorious Witches Trial, 77 Sir Thomas Browne, the most distinguished physician of the time and author of Religio Medici, testified before the jury to his belief in witches, elaborating his opinion by a scientific explanation of the fits to which they were subject. Again it is not clear who summoned him, although he testified in open court. From the report we learn that

"There was also Dr. Brown of Norwich, a person of great knowledge, who after this evidence given [testimony of the fact witnesses], and upon view of the three persons in Court, was desired to give his opinion, what he did conceive of them, and he was clearly of opinion, that the persons were bewitched; ..."

By 1678 we have cases where there are experts on both sides. In that year in Rex v.Pembroke, ${ }^{48}$ a murder trial, both the prosecution and defense called physicians to testify to the causes of symptoms observed in an autopsy and to the proposition whether a person can die of wounds without fever. Similarly, in the next year in another murder trial, Rex $v$. Green et al, ${ }^{49}$ two surgeons, who had viewed the body of the victim, were summoned by the prosecution in order to give their opinion as to the cause and manner of death and as to the length of time the victim had been dead when viewed. In 1682, again in a murder prosecution, Rex $v$. Coningsmark, ${ }^{50}$ a surgeon was summoned by the crown to offer his opinion as to the nature of bullet wounds, the cause of death, and also the type of wound which certain bullets could produce. And in the celebrated trial of Spencer Cowper for the murder of Sarah

${ }^{2}$ Act of $\times 562-1563,5$ Eurz. c. 9, 512 .

${ }^{20}$ Alsop v. Bowtrell, Cr. Jac. 54I (I6ro). (Italics added.)

${ }^{47}$ Rex v. Cullender and Duny, 6 How. St. Tr. 687 (1665).

2s 6 How. St. Tr. I310 (1678).

${ }^{4} 7$ How. St. Tr. 159 (1679).

${ }^{50} 9$ How. St. Tr. I (I682). 
Stout in $1699^{51}$ there was much medical testimony produced by the prosecution and defense concerning the cause of death. However, it would seem that at least in mercantile matters, the court continued for some time to summon skilled persons to aid it. In Buller v. Crips, ${ }^{52}$ in which an indorsee-plaintiff had framed his declaration in an action against the maker of the note "upon the custom of merchants as upon a bill of exchange," Chief Justice Holt on his own initiative sought out two merchants for their opinion as to the negotiability of the paper in question:

"At another day Holt, Chief Justice, declared that he had desired to speak with two of the most famous merchants in London, to be informed of the mighty ill consequences that it was pretended would ensue by obstructing this course; and they had told him, it was very frequent with them to make such notes, and that they looked upon them as bills of exchange, and that they had been used for a matter of thirty years, and that not only notes, but bonds for money, were transferred frequently, and indorsed as bills of exchange." (Italics added.).

By the 18th century the party system of experts had become firmly settled.63 In 1782 the leading case of Folkes v. Chadd ${ }^{54}$ was decided by Lord Mansfield. This case, an action of trespass before a jury, established the sphere in which expert testimony would be admissible. The issue involved was the cause of a harbor filling up. The plaintiff produced a well known engineer, Mr. Smeaton, whose opinion as to the cause of the injury was requested. This evidence was objected to on the ground that it was a matter of opinion, which could not be the foundation for the verdict of a jury because the verdict should be based entirely on facts. On appeal, Lord Mansfield held the evidence permissible, saying:

"The question is, to what has this decay been owing? The defendant says to this bank, Why? Because it prevents the backwater. That is a matter of opinion; the whole question is a matter of opinion, from facts agreed upon. . . . On the first trial, the evidence of Mr. Milne, who has constructed harbors, and observed the effect of different causes operating upon them, was received; and it never entered into the head of any man at the bar that it was improper. . . . On the motion for the new trial, the receiving Mr. Milne's evidence was not objected to as improper; but.it was moved for on the ground of that evidence being a surprise; and the ground was material, for in matters of science the reasonings of men of science can only be answered by men of science. The court, considering the evidence as proper, directed the opinions to be printed, and to be exchanged. Under the persuasion of this being right, the parties go down to trial again, and Mr. Smeaton is called. A confusion now arises from a misapplication of terms. It is objected that Mr. Smeaton is going to speak, not as to facts, but as to opinion. That opinion is deduced from facts which are not disputed-the situation of banks, the course of tides and of winds, and the shifting of sands. His opinion, deduced from all these facts, is, that mathematically speaking, the bank may contribute to the mischief, but not sensibly. Mr. Smeaton understands the construction of harbors, the causes of their destruction, and how remedied. In matters of science no other witnesses can be called. . . I cannot believe

13 How. St. Tr. I106 (I699).

66 Mod. 30 (1705).

o Holdsworth, op. cit. supra note 4, at 212; 4 WIGMORE, op. cit. supra note 2, 51917 ("But by the latter part of the 1700 's he took his place with others as a mere witness to the jury").

\& Doug. I57 (1782). 
that where the question is, whether a defect arises from a natural or artificial cause, the opinions of men of science are not to be received. . . . The cause of the decay of the harhor is also a matter of science. ... Of this, such men as Mr. Smeaton alone can judge. Therefore we are of opinion that his judgment, formed on the facts, was very proper evidence." (Italics added.)

We see that by the time Lord Mansfield wrote, the necessity for skilled assistance was clearly recognized, and the ordinary method was production of expert witnesses by the parties. It appears, then, that there have been three methods of employing skilled knowledge for the decision of issues: special juries, experts called to aid the court, and party experts. This last is comparatively modern, but is the one best known to us.

\section{The Opinion Rule}

With the development of jury trial and of proof by witnesses-that is, an appreciation of a distinction between juror and witness-there begins to take shape the law of evidence. This change, we have noted, begins in the sixteenth century. To the influence of jury trial may be attributed the most characteristic element of the law of evidence, the exclusionary rules, ${ }^{55}$ which determine the competency of witnesses and the admissibility of evidence. Their original purposes were to guard the jury from being misled by the testimony produced and to keep the considerations of the jury within the issues of the pleadings. These rules, however, developed slowly; Holdsworth observes that "in the first half of the seventeenth century, we get the phenomenon noted by Hudson (Star Chamber, p. 210) that 'the books of common law do yield small direction for examination of witnesses; and the civilians are therein far too copious." "56 And Wigmore says that up to the I700's there was no definite idea that opinion testimony or the like was proper or improper and that the thought on the subject was negligible. ${ }^{57}$

Among the foremost of the exclusionary rules is the so-called "opinion" rule. The substance of it, as applied today, is that a witness testifying to his experience in regard to the matters in issue should testify to the "facts" observed and not to his own opinion or inference therefrom. After such testimony is produced, the trier of fact is deemed capable of making the inferences or framing the opinion. ${ }^{58}$ Only when the witness has some special skill or experience which would aid the tribunal in arriving at its conclusions from the operative facts is a witness permitted to express an opinion. Wigmore's contention that the true theory of the rule is thereby to eliminate superfluous testimony seems to be more convincing than the other two reasons commonly offered as the basis for excluding opinion-that to permit the witness to give his opinion would be to permit him to usurp the functions of the jury and that it concerns the very issue before the jury, both of which reasons seem

is Holdsworth, op. cit. supra note 4 , at 127 . See also, Thayer, op. cit. supra note 1 , Introduction.

us Hozdsworth, op. cit. supra note 4 , at 180 .

67 Wigmore, op. cit. supra note 2, \$rg17.

${ }_{4}$ WIGMORE, op. cit. supra note $2, \$ 1918$. 
to be very similar. ${ }^{59}$ Yet a jealous regard for the province of the jury seems to have been influential in shaping the strictness of the law in regard to opinion evidence. So long, however, as the jury is responsible for the ultimate determination of facts, the usurpation argument seems lacking in substance. Lord Mansfield apparently had in mind the same idea as Wigmore has put forth, when although noting the irrelevancy of opinion evidence by an insurance broker in regard to the materiality of representations and concealments, he sustained the verdict of the jury in Carter ข. Boehm::00

"Great stress was laid upon the opinion of the broker. But we think the jury ought not to pay the least regard to it. It is mere opinion, which is not evidence. It is opinion after an event. It is opinion without the least foundation from any previous precedent or usage. It is opinion which, if rightly formed, could only be drawn from the same premises from which the court and jury were to determine the cause; and therefore it is improper and irrelevant in the mouth of a witness."

So the opinion rule today is one of exclusion, designed to limit the witness to the presentation of those matters upon which the jury is qualified to pass judgment. This exclusionary rule has one great exception; it does not apply to expert witnesses. And it provides the principal legal distinction between the ordinary and the expert witness in our law. Some instances of this exclusionary principle in operation are opinions as to: the amount of damage to cattle by feeding them inferior hay; ${ }^{01}$ whether a person's conduct was careful or careless; ${ }^{62}$ ability of a person in a certain location and at a certain distance to overhear a conversation; ${ }^{83}$ whether two people were attached to each other and whether their conduct towards each was affectionate; ${ }^{64}$ the amount of profits claimed to be lost (a schedule prepared by the plaintiff had been admitted in evidence; "in effect, he stated his opinion as to the loss of profits resulting ...."); ${ }^{65}$ whether the origin of a fire was incendiary or not, ${ }^{66}$ the length of time a fire had been burning, ${ }^{67}$ whether an ordinarily competent signature clerk would be put on suspicion by slight change in spelling of a name, ${ }^{68}$ whether certain transactions and conversations amounted to an agreement, ${ }^{00}$ the amount of force necessary to remove a passenger. ${ }^{70}$

The original foundation of this rule, to use Wigmore's terminology, is in the requirement of "Testimonial Knowledge," that is, that the witness know from a factual basis whereof he speaks and not merely hazard a guess." "Opinion" orig-

${ }^{4} 4$ Wigmore, op. cit. supra note 2, \$\$1918, 1920-1921.

${ }_{3} 3$ Burr. 1906 (1766). (Italics added.)

${ }^{\infty}$ McCarragher v. Rogers, 120 N. Y. 526, 24 N. E. 812 (1890).

${ }^{\infty}$ McLaughlin v. Webster, r4I N. Y. 76, 35 N. E. 108r (1894).

"Pearce v. Stace, 207 N. Y. 506, ror N. E. 434 (1913).

${ }^{\infty}$ Moran v. Standard Oil Co., 21 I N. Y. 187, 105 N. E. 217 (1914).

${ }^{\infty}$ People v. Grutz, 212 N. Y. 72, 105 N. E. 843 (1914).

"Goodman v. Ins. Co., 222 N. Y. 121, 118 N. E. 523 (1917).

${ }^{\circ}$ Noah v. Savings Bank, 225 N. Y. 284 , 122 N. E. 235 (1919).

${ }^{\infty}$ Hillock v. Grape, III App. Div. (N. Y.) 720, 724, 97 N. Y. Supp. 823 (1906).

${ }^{70}$ Regner v. R. R., 74 Hun 202, 26 N. Y. Supp. 625 (1893).

$\pi_{4}$ WIGMORE, op. cit. supra note 2, \$1917. 
inally was synonymous with guesswork. What the tribunal was interested in was matter which had fallen within the personal observations of the witness-an experience of the witness which was sufficiently definite to rely upon. That such was the early idea of "opinion" may be gathered from the statement in Adams v. Canon" in 1622 , for which Lord Coke is cited as authority:

". . . it is not satisfactory for the witness to say, that he thinks or persuadeth himself; and that for two reasons by Coke: Ist, Because that the Judge is to give an absolute sentence, and therefore ought to have more sure ground than thinking; 2dly, The witness cannot be prosecuted for perjury; ..."

Even under the older mechanical system of determining litigation, this requirement of personal observation attached in the few instances where witnesses, preappointed at the time of certain transactions for the purpose of proof; were allowed to come forth in court; what they testified to had to be "de visu et auditu."73 When the institution of witnesses became an accepted part of trial procedure, this testimonial requirement attached and continued. ${ }^{74}$

The importance of this requirement was emphasized when those with specialized experience were brought into the trial of issues as witnesses to the jury. Previously the need of this kind of knowledge had been supplied by specialized juries or by the court summoning experts, and therefore no question arose as to the source of the expert's information. But when the expert became a witness, his testimony differed materially from that of the ordinary witness, for the primary purpose of his testimony was to put forth the opinion or inferences of a skilled person on the matter in issue. To justify this kind of testimony was indeed a question, for the necessity of such information existed then as much as it ever had; yet on the other hand was the idea that mere opinion was not evidence. Finally, as has been seen, Lord Mansfield, in Folkes v. Chadd,75 decided the matter, and expert testimony by "men of science" in the form of opinion evidence as to a "matter of science" was proper testimony to bring before a tribunal. During the I8th century then, we have a rule developed that opinion evidence, opinion without a fact-knowledge basis, is not proper evidence; but this rule does not apply to the testimony of men of science who are not acquainted first-hand with the matter.

From this foundation of the rule, Wigmore traces the shift to the modern theory, viz., the exclusion of superfluous testimony. ${ }^{76}$ The testimony of an expert was considered an exception to the requirement that the witness speak from factual experience, because the opinion of the expert was helpful to the jury. However, if the jury was capable of drawing inferences from the factual testimony presented, the opinion of a witness thereon would not provide any help and, therefore, would be superfluous. Thus, the ordinary witness is silenced when he would state his

\footnotetext{
72 Dyer $53 \mathrm{~b}$, note a ( 1622$)$.

9 HOLDswORTH, op. cit. supra note 4, Pp. 2 II-2I2.

7I WIGMORE, op. cit. supra note $2, \$ 657,4$ id. \$1917.

${ }^{75}$ Supra note $5 \mathrm{I}$.

${ }^{70}$ WIGMORE, op. cit. supra note 2, 519r7.
} 
opinion or inference. Opinion testimony is no longer excluded because of lack of "Testimonial Qualifications," but rather as a rule of "Auxiliary Policy."77

\section{The Hypotheticat Question}

The development of expert testimony and of the modern opinion rule has given rise to another distinctive feature of the law of evidence, the requirement of the hypothetical question in obtaining the opinion of an expert who has not personally observed the "facts" to which his opinion is related. The substance of this requirement is that when an expert witness lacks personal observation, the examiner in his question must set forth merely as an assumption or hypothesis the detailed items of evidence which are to form the basis of the opinion. ${ }^{78}$ Thus a means is provided for the jury (or judge where he is the trier of fact) to determine the value of the opinion by testing its premises-which often include evidence disputed by the opposing party - with the facts as ultimately found by the jury after all the evidence has been produced. Only if the data as assumed by the questions coincide with the determination of facts made by the jury is the opinion of the expert pertinent. If the jury does not accept the assumed version, the foundation of the opinion drops out and accordingly the opinion must be discarded. Of course, if the expert has had personal observation, he already has the basis for an opinion which he may state directly, since he is as available as an ordinary "fact" witness for examination as to the items upon which opinion rests. ${ }^{79}$

A fairly well-defined body of law has developed about the use of the hypothetical question. In the question may be included any or all of the matters which the adduced evidence tends to support. So long as the detailed data comprise facts likely to be considered by the tribunal, the examiner, is not restricted in the content of the question, and he may frame it according to any theory which there is evidence to support. $^{80}$ In this way opinion evidence which is useless and irrelevant because unrelated to the fact evidence is curtailed. Usually the question must also specify what the assumed facts are so that the jury may readily analyze the reasons for the opinion. ${ }^{81}$ Accordingly, certain types of questions are improper. For instance, the following forms may not usually be employed: "Upon all the testimony in the case, what is your opinion?" "Upon the testimony which you have heard in the case, what is your opinion?" And questions such as "Assuming the truth of the testimony for the plaintiff or the defendant," or, "Assuming the truth of the testimony of certain witnesses, what is your 'opinion?" generally are objectionable. The foregoing limitations have now crystallized into rather strict rules; and we may see reversals in the highest courts because of a failure to follow this method of examination. ${ }^{82}$

\footnotetext{
$\pi_{4}$ WIGMORE, op. cit. supra note 2,51918 .

TI. $\$ 675$.

${ }^{73}$ I WIGMORE, op. cit. supra note 2, 5676 .

${ }^{\infty}$ Id. $\$ 682$.

${ }^{2}$ Id. 3681 . This section contains an excellent discussion of proper and improper methods of "particularization of premises to be used."

Wiebert v. Hannan, 202 N. Y. 328,85 N. E. 688 (x911); Marx v. Ontario Beach Co., 211 N. Y. 33, ro5 N. E. 97 (191.4).
} 
Yet in the earliest cases dealing with expert testimony, there seems no vestige of these rules. Thus, in the Witches Trial, ${ }^{83}$ for instance, the report tells us that Dr. Browne, after the testimony of the "fact" witnesses and upon view of the persons in court, was asked to give his opinion. Yet there is no detailing of facts previously testified to or anything in the nature of a hypothetical question; just the learned doctor's own opinion.

It is during the I700's, when the problem presented by considering "opinion" as distinguished from "fact" or personal observation emerges, that we first see reference to the requirement of detailing the matter upon which an opinion is desired. ${ }^{84}$ And the references from then on would seem to indicate that such a method was intended primarily to aid the tribunal. In the trial of Earl Ferrers ${ }^{85}$ in 1760 , for murder, the defendant, examining a doctor on the matter of insanity, put the following question: "Please to inform their lordships whether any, and which of the circumstances which have been proved by the witnesses are symptoms of lunacy."

This was objected to by the Attorney-General, to which objection the Earl of Hardwicke, Ferrers' counsel, agreed:

"My lords, this question is too general, tending to ask the doctor's opinion upon the result of the evidence, and is very rightly objected to by the counsel for the crown; if the noble lord at the bar will divide the question, and ask whether this or that particular fact is a symptom of lunacy, I dare say they will not object to it."

Whereupon the defendant specified certain acts and asked the doctor "please to inform their lordships" whether such acts indicated lunacy. It will be seen that the objection could best be met by the examiner setting forth the facts, the essence of the hypothetical method.

The next case of interest relating to this method of examination is the trial of Lord Melville ${ }^{86}$ in 1806 for misappropriation of public funds. The prosecution, after showing how certain sums were misapplied, proposed to show the gain derived from their use. An accountant was called to prove this by his calculations. This was objected to as an improper subject for evidence, being merely assumed matter and opinion, which the tribunal might well draw for itself. The calculations were allowed in evidence. The discussion of the Lords on this point show that they considered the proposed matter in the nature of a hypothetical question, which would justify its admission:

A Lord: ". . . the data and facts stand as they did, it is a mere hypothetical question to the witness. If the facts stand so and so, what is the arithmetical result?"

Ld. Chanc.: ". . . it proceeds on certain data. If you take away the foundation upon which it is made, which is matter for the court afterward, there is an end of the superstructure."

\footnotetext{
Supra note 47.

"In all the cases discussed above, which arose in the seventeenth century, the expert witnesses had had personal observation of the subject matter.

${ }^{* 5}$ Ig How. St. Tr. 886 (1760). $\quad 0_{29}$ How. St. Tr. 606 (1806).
} 
Another Lord: "All the inconvenience that might result from this entry, would be obviated by stating, that if it is proved, or shall be proved, that such and such facts exist, that is the calculation of the profits; but that will not be an admission of the facts." (Italics added.)

When it was shown that the validity of the calculations depended upon the existence of specific facts, there was no hesitancy in accepting the evidence, for the tribunal was then in a position to apply the calculations to its determination of the litigated transaction.

Beckwith v. Sydebotham, ${ }^{87}$ the following year, shows that the hypothetical question was by then the accepted method to elicit expert opinion where the facts were disputed. Lord Ellenborough held admissible the opinion of ship surveyors, formed on the basis of certain testimony, as to the seaworthiness of a ship, and he concluded:

"As the truth of the facts stated to them was not certainly known, their opinion might not go for much; but still it was admissible evidence. The prejudice alluded to [admitting an opinion upon a statement that might be false] might be removed by asking them in crossexamination, what they should think upon the statement of facts contended for on the other side."

This method is proper because the trier of fact is thereby enabled to determine, in its deliberations, whether or not the opinion might "go for much."

Perhaps the best known judicial expression on the examination of an expert witness, who lacks personal observation, is contained in the discussion of the judges in M'Naghten's Case ${ }^{88}$ in 1843 . The fifth question put was:

"Can a medical man conversant with the disease of insanity, who never saw the prisoner previously to the trial, but who was present during the whole trial, and the examination of all the witnesses, be asked his opinion as to the state of the prisoner's mind at the time of the commission of the alleged crime, or his opinion whether the prisoner was conscious at the time of doing the act that he was acting contrary to law, or whether he was laboring under any and what delusions at the time?"

\section{Mr. Justice Maule's opinion was:}

"In principle, it is open to this objection, that, as the opinion of the witness is founded on those conclusions of facts which he forms from the evidence, and as it does not appear what those conclusions are, it may be that the evidence he gives is on such an assumption of facts as makes it irrelevant to the inquiry. But such questions have been very frequently asked, and the evidence to which they are directed has been given, and has never, that I am aware of, been successfully objected to."

The first sentence in the passage quoted points to the vice in an opinion given by an expert which is not in response to a question setting forth the factual premises. The formulation of an opinion under such circumstances involves a selection by the expert from amongst disputed facts, without making evident to the body ultimately responsible for determining the truth of the matter what the facts selected are. Consequently the jury cannot tell whether the opinion is based on the same facts which it finds to be true.

or I Camp. Ir6 (1807).

20 CI. \& F. 207 (1843). 
The second sentence indicates that the precaution, noted as early as the trial of Earl Ferrers in 1760 , of having the factual bases of the expert's opinion detailed, had not been consistently followed in subsequent cases. But the other justices were not content to follow Mr. Justice Maule in his acquiescence in this practice. Lord Chief Justice Tindal, speaking for them, doubted the validity of the questions in the terms put

"because each of those questions involves the determination of the truth of the facts deposed to, which it is for the jury to decide, and the questions are not mere questions upon a matter of science, in which case such evidence is admissible."

This ruling afforded a firm basis in precedent for the requirement of the detailed hypothetical question in the examination of expert witnesses where, at least, the facts are in dispute. Where the facts are admitted or undisputed, the Lord Chief Justice conceded that the more general form of question might be employed, but only as a matter of convenience and not of right.

That in the United States the requirement of the hypothetical question was taking form about the same time as in England is made evident by a charge to the jury in a murder trial in a federal court as early as $185^{1 .} .^{89}$ Referring to the testimony of physicians relative to the defense that the defendant was afflicted with delirium tremens, Mr. Justice Curtis, who in the same year became a member of the United States Supreme Court, pointed to the reason for use of the hypothetical method in the following statement:

"They were not, as you observed, allowed to give their opinions upon the case; because the case, in point of fact, on which anyone might give his opinion, might not be the case which you, upon the evidence, would find; and there would be no certain means of knowing whether it was so or not. It is not the province of an expert to draw inferences of fact from the evidence, but simply to declare his opinion upon a known or hypothetical state of facts; and, therefore, the counsel on each side have put to the physicians such states of facts as they deem warranted by the evidence, and have taken their opinions thereon." (Italics added.)

The emphasis in these early opinions on the respective functions of expert and jury doubtless gave impetus to an explanation of requiring the use of the hypothetical question which is frequently met with in subsequent cases and which we have already encountered in connection with the opinion rule. The question is said to be necessary to prevent the expert from usurping the province of the jury.

It is true that an expert required to render an opinion on the basis of evidence which is in dispute would, as has been seen, be obliged, if a hypothetical question were not put to him, to select as a basis for his opinion those facts which he believed to be true, a necessity which the jury also faces. But even if the expert were permitted to do this, the jury's obligation to determine the facts would remain unchanged. However, not only would their function be duplicated by the expert, but

${ }^{8} 1$ Curt. I, Fed. Cas. No. 15,679 (C. C. D. Mass. I851). 
the value of his opinion to the jury in the discharge of its duty would be greatly diminished. It is in its design to assure the clear, orderly, and helpful presentation of expert opinion evidence to the jury that the true explanation of the hypothetical question requirement is to be found.

An excellent illustration of a court's consideration of the usurpation and of the proper theory is found in the opinion of the New York Court of Appeals in People v. McElvaine.80 The propriety of the following question, put to a physician who had attended the trial on the issue of the defendant's sanity, was before the court: "Based upon the whole testimony of the prosecution and the defense ... and everything that you have heard sworn to here, now will you answer the question?"01

Chief Judge Ruger, writing for the court, could not "doubt but that this question was improper":

"The witness was thus permitted to take into consideration all the evidence in the case ... determine the credibility of witnesses, the probability or improbability of their statements. ... It cannot be questioned but that the witness was by the question put in the place of the jury, and was allowed to determine upon his own judgment what their verdict ought to be. ..."

But though this may be the result of such a question, the reason why it is not competent is that

"it would then be impossible for the jury to determine the facts upon which the witness bases his opinion, and whether such facts were proved or not. Suppose the jury conclude that certain facts are not proved, how are they in such an event to determine whether the opinion is not, to a great degree, based upon such facts? When specific facts, either proved or assumed to have been proved, are embraced in the question, the jury are enabled to determine whether the answer to such question is based upon facts which have been proved in the case or not, and whether other facts bearing upon the correctness and force of the answer are contained therein, or have been omitted from it; but in the absence of such a question, the evidence must always be, 10 a certain extent, uncertain, unintelligible, and, perhaps, misleading. ..." (Italics added.)

Viewed in the light of this explanation, the requirement that the hypothetical question be employed in eliciting expert opinion, is revealed as but a logical step in the development of the use of expert testimony in the common law procedure for the trial of causes. Indeed, it merits Wigmore's characterization as "one of the few truly scientific features of the rules of Evidence." ${ }^{12}$ But it is significant to note that Wigmore also asserts that "The hypothetical question, misused by the clumsy and abused by the clever, has in practice led to intolerable obstruction of truth." 93

\footnotetext{
${ }_{121}$ N. Y. 250,24 N. E. 465 (1890).

an is interesting to note the similarity between this question and the fifth question put to the judges in McNaughten's Case, supra note 88.

I WTGMORE, op. cit. supra note 2, 5686.

*1bid. Dean Wigmore proposes that the hypothetical question be abolished as a requirement and that its use, except on cross-examination, be left to the discretion of the court.
} 